\title{
OPTIMIZATION OF RUNWAY CAPACITY AT CGK AIRPORT
}

\author{
Ramandika Agung Sampurno ${ }^{1}$, Kevan Rinodistira ${ }^{2}$, Wynd Rizaldy ${ }^{3}$ \\ 1. STMT Trisakti, 2. STMT Trisakti, 3. STMT Trisakti \\ $\triangle$ corresponding author: ramandikaagung04@ gmail.com
}

\begin{abstract}
Runway complexes are the principal bottlenecks of airports, and therefore knowledge of their capacity is of vital importance (Zografos, Stamatopoulos, \& Odoni, 1997). However, Take-off and landings have to be assigned to a runway and a time while meeting the sequence-dependent separation requirements and minimizing the delays (Janić, 2017). At an operational level, runway scheduling seek to determine effective aircraft schedules over one or multiple runways using pertinent factors that affect the flow of air traffic movement at Soekarno-Hatta International Airport (Farhadi, Ghoniem, \& Al-Salem, 2014). Therefore, this article discusses the optimization of runaway capacity at CGK airport or Soekarno-Hatta International Airport using descriptive quantitative-qualitative method to know the air traffic movement. The result in table one which showed the peak, moderate, and low hour on day five revealed that the capacity of runway at Soekarno-Hatta International Airport per day reached 1687 aircraft movements. Then, table two and interview results confirmed that Soekarno-Hatta International Airport could handle the aircraft movement until 72 flights per hour, fewer than that of Heathrow Airport could which reached until 89 flights per hour. Moreover, it is predicted that aircraft movement in Soekarno-Hatta International Airport will probably increase in 2019.
\end{abstract}

Keywords: Flights Movement, Runway Capacity, Airport

\section{Introduction}

Transportation services have evolved from efforts to serve public interest to commercial service. One mode of transportation that is growing rapidly in Indonesia is air transportation (Marty, 2016). Hence, this research aims at investigating the optimization of runway capacity at Soekarno-Hatta International Airport which is an important issue since runway is the place for an aircraft to land and take-off; therefore, runway becomes the most critical factor to support enforcement in an aviation industry. This research focuses on finding out whether or not Soekarno-Hatta International Airport needs additional runway. As Soekarno-Hatta International Airport becomes a large hub for domestic and international flights (Perdamaian, Budiarto, \& Ridwan, 2013), and Soekarno-Hatta International Airport is an Indonesian main 
gateway, which is also named as the 11th busiest airport in the world by Airport Council International (ACI) in 2012 and the 4th busiest in Asia with 51.1 million passengers in 2011 (Martono \& Marina, n.d.). Therefore, the airside capacity of an airport depends directly on the runway system capacity (Skorupski \& Wierzbicki, 2017).

The number of aircraft movements keeps increasing in this airport every year. Therefore, the airport needs expansion of the runway to handle that because one of the most significant factors that affects the location of airport elements and influence ease aircraft movement is the optimum runway orientation. On March 29, 2016, Budi Karya Sumadi as the President Director of Angkasa Pura II introduced the plan to build a new runway at this airport to expand its capacity to meet the continuously improving runway traffic.

The problem is the runway that Soekarno-Hatta International Airport has can't handle the overload of aircraft movement (take-off and landing). Moreover, to ensure the highest level of safety for airport surface operations, the airport is required to implement a Safety Management System (SMS) which is a systematic approach to safety that strives to assess and continuously improve the safety of an entire system. It therefore requires the assessment of all system components and their interactions for hazards and associated safety risks, not exception the runway. The management of safety comprises of two core operational activities: safety risk management, and safety assurance (Wilke, Majumdar, \& Ochieng, 2015).

According to the problem above, Budi Karya Sumadi said that development of the third runway has a significant role to resolve the air traffic at Soekarno-Hatta International Airport. Hence, in 2018 Angkasa Pura II predicted the number of aircraft movements is more than 420.000 aircraft movements for a year. In order to anticipate the soaring number of passengers, the government is preparing to build runway number three which is targeted to complete in 2017 (P. Ricardianto \& Rifni, n.d.). Although it seems too late, this 
solution given by Angkasa Pura II is the most realistic if compared with the alternative to re-activate the old airport (Pondok Cabe airport).

Furthermore, the government has been seriously and fast developing various infrastructures such as airport, terminal, toll road (highway), and so on (Simarmata \& Keke, 2017). The purpose is to expedite the air traffic movement and make the flight schedule able to operate in accordance with the determined time.

\section{Method}

The research is based on descriptive quantitative-qualitative method involving document analysis and interview. There were two interviewees who were male with age around $\pm 50-60$ years old. One of the participants was Director of Airport and Technological Development at Angkasa Pura II while the other was Air Traffic Controller officer at Air Navigation Indonesia. Interview and flight schedule from the website soekarnohatta-airport.co.id became the main data. The Face-to-face interview method with open-ended questions which became the primary data for this research was to clarify the flight schedule from the website. We asked all interviewees with the same questions and they explained the answers. To add, similar information was also taken from Heathrow Airport (as the main benchmark), Kuala Lumpur International Airport, and Suvarnabhumi Airport. We quantitatively measured the flight schedules to classify the data hourly on a table. Flight schedule on the website showed record content of all flight schedule at Soekarno-Hatta International Airport, yet, this research only took the flight schedule hourly within 24 hours on day five. The data was classified on a table based on the peak hour, moderate hour, and low hour. Secondly, interview was conducted to compare the actual data with website flight schedule data. In the end, the results were compared with those of Heathrow Airport (as the main benchmark), Kuala Lumpur International Airport, and Suvarnabhumi Airport. 


\section{Discussion and Result}

The flight schedule at Soekarno-Hatta International Airport available on the website soekarnohatta-airport.co.id informed readers on: Time schedule, Destination, Airlines, Aircraft code, Terminal, Additional flight information, and Flight radar. Then the information above was classified into a table on the following items: Time Schedule, Departure (including international and domestic flights), Arrival (including international and domestic flights), and Total flights. While this is a crude estimation, it enables us to calculate an aircraft traffic impact measure based on the time per hour. Using the flight schedule as the base of our data, we also consider low and rush per hour of the air traffic flow. The resulting air traffic flow can be seen in table one.

Table 1.

Flight scheduled data at Soekarno-Hatta International Airport (hourly within 24 hours on

\begin{tabular}{|c|c|c|c|c|}
\hline \multicolumn{5}{|c|}{ day five) } \\
\hline NO. & TIME & DEPARTURE & ARRIVAL & TOTAL \\
\hline 1. & $00.00-01.00$ & 14 & 9 & 23 \\
\hline 2. & 01.00-02.00 & 10 & 4 & 14 \\
\hline 3. & 02.00.03.00 & 3 & $\mathbf{0}$ & 3 \\
\hline 4. & 03.00-04.00 & 2 & 0 & 2 \\
\hline 5. & 04.00-05.00 & 15 & 2 & 17 \\
\hline 6. & 05.00-06.00 & 55 & 0 & 55 \\
\hline 7. & 06.00-07.00 & 38 & 5 & 43 \\
\hline 8. & 07.00-08.00 & 37 & 49 & 86 \\
\hline 9. & $08.00-09.00$ & 45 & 59 & 104 \\
\hline 10. & $09.00-10.00$ & 57 & 25 & 82 \\
\hline 11. & $10.00-11.00$ & 36 & 57 & 93 \\
\hline 12. & $11.00-12.00$ & 53 & 43 & 96 \\
\hline 13. & $12.00-13.00$ & 38 & 58 & 96 \\
\hline 14. & $13.00-14.00$ & 57 & 48 & 105 \\
\hline 15. & $14.00-15.00$ & 53 & 49 & 102 \\
\hline 16. & $15.00-16.00$ & 35 & 44 & 79 \\
\hline 17. & $16.00-17.00$ & 61 & 48 & 109 \\
\hline 18. & $17.00-18.00$ & 51 & 66 & 117 \\
\hline 19. & $18.00-19.00$ & 46 & 40 & 86 \\
\hline 20. & $19.00-20.00$ & 48 & 63 & 111 \\
\hline 21. & $20.00-21.00$ & 27 & 53 & 80 \\
\hline 22. & $21.00-22.00$ & 23 & 67 & 90 \\
\hline 23. & $22.00-23.00$ & 14 & 31 & 45 \\
\hline 24. & $23.00-24.00$ & 18 & 31 & 49 \\
\hline & TOTAL & 836 & 851 & 1687 \\
\hline
\end{tabular}


Note:

\begin{tabular}{|l|l|}
\hline & Describe the peak hours of the aircraft movement \\
\hline & Describe moderate hours of the aircraft movement \\
\hline & Describe the low hours of the aircraft movement \\
\hline
\end{tabular}

Next, even though the length of runway of Heathrow International Airport is similar with that of Soekarno-Hatta International Airport, Heathrow International Airport runway is considered more optimal. The result on table two indicated that the length of runway is not the only one factor to affect the runway capacity and aircraft movement, and it is consistent with the real market. Thus, the model and type of the runway may affect the runway capacity expansion (Takebayashi, 2011). Table two. below described the following: Name of the airport, Length of runway, Type of runway, Runway capacity, Aircraft movement, Terminal and Cross Taxiway.

Table 2.

Benchmarking Runway capacity per hour for four International Airport

\begin{tabular}{|c|c|c|c|c|c|c|}
\hline NO. & $\begin{array}{l}\text { NAME OF THE } \\
\text { AIRPORT }\end{array}$ & $\begin{array}{l}\text { LENGTH } \\
\text { OF } \\
\text { RUNWAY }\end{array}$ & $\begin{array}{l}\text { TYPE OF } \\
\text { RUNWAY }\end{array}$ & $\begin{array}{l}\text { RUNWAY } \\
\text { CAPACITY }\end{array}$ & $\begin{array}{l}\text { AIRCRAFT } \\
\text { MOVEMENT }\end{array}$ & $\begin{array}{c}\text { Terminal\& } \\
\text { Cross } \\
\text { Taxiway }\end{array}$ \\
\hline 1 & $\begin{array}{l}\text { SOEKARNO- } \\
\text { HATTA } \\
\text { INTERNATIONAL } \\
\text { AIRPORT }\end{array}$ & $\begin{array}{l}07 \mathrm{R} / 25 \mathrm{~L} \\
12.008 \mathrm{ft} \text { or } \\
3.660 \mathrm{~m} \\
07 \mathrm{~L} / 25 \mathrm{R} \\
11.811 \mathrm{ft} \text { or } \\
3.600 \mathrm{~m}\end{array}$ & $\begin{array}{l}\text { Multiple } \\
\text { Runway }\end{array}$ & $\begin{array}{l}72 \text { flights } \\
\text { per hour }\end{array}$ & 369.74 & $3 \& 1$ \\
\hline 2 & $\begin{array}{l}\text { KUALA LUMPUR } \\
\text { INTERNATIONAL } \\
\text { AIRPORT }\end{array}$ & $\begin{array}{l}14 \mathrm{~L} / 32 \mathrm{R} \\
13.530 \mathrm{ft} \text { or } \\
4.124 \mathrm{~m} \\
14 \mathrm{R} / 32 \mathrm{~L} \\
13.307 \mathrm{ft} \text { or } \\
4.056 \mathrm{~m}\end{array}$ & $\begin{array}{l}\text { Multiple } \\
\text { Runway }\end{array}$ & $\begin{array}{l}78 \text { flights } \\
\text { per hour }\end{array}$ & 242.615 & 2 \\
\hline
\end{tabular}


Table 2, cont.

Benchmarking Runway capacity per hour for four International Airport

\begin{tabular}{|c|c|c|c|c|c|c|}
\hline \multirow{2}{*}{3} & \multirow{2}{*}{$\begin{array}{l}\text { SUVARNABHUMI } \\
\text { AIRPORT }\end{array}$} & $\begin{array}{l}01 \mathrm{R} / 19 \mathrm{~L} \\
13.123 \mathrm{ft} \text { or } \\
4.000 \mathrm{~m}\end{array}$ & \multirow{2}{*}{$\begin{array}{l}\text { Multiple } \\
\text { Runway }\end{array}$} & \multirow{2}{*}{$\begin{array}{l}76 \text { flights } \\
\text { per hour }\end{array}$} & \multirow{2}{*}{336.345} & \multirow{2}{*}{2} \\
\hline & & $\begin{array}{l}01 \mathrm{~L} / 19 \mathrm{R} \\
12.139 \mathrm{ft} \text { or } \\
3.700 \mathrm{~m}\end{array}$ & & & & \\
\hline \multirow{2}{*}{4} & \multirow{2}{*}{$\begin{array}{l}\text { HEATHROW } \\
\text { INTERNATIONAL } \\
\text { AIRPORT }\end{array}$} & $\begin{array}{l}09 \mathrm{~L} / 27 \mathrm{R} \\
12.802 \mathrm{ft} \text { or } \\
3.902 \mathrm{~m}\end{array}$ & \multirow{2}{*}{$\begin{array}{l}\text { Multiple } \\
\text { Runway }\end{array}$} & \multirow{2}{*}{$\begin{array}{c}89 \text { flights } \\
\text { per hour }\end{array}$} & \multirow{2}{*}{474.963} & \multirow{2}{*}{$5 \& 7$} \\
\hline & & $\begin{array}{l}09 \mathrm{R} / 27 \mathrm{~L} \\
12.008 \mathrm{ft} \text { or } \\
3.660 \mathrm{~m}\end{array}$ & & & & \\
\hline
\end{tabular}

This section provides the results of the case study and is divided into two parts. First, the results of the flight schedule of the whole airlines at SoekarnoHatta International Airport per hour on day five were presented and discussed, while the second part provided a benchmarking of runway capacity analysis from some countries.

Discussion

Based on the flight schedule data taken on November 3, 2017 on table one, the calculation of average 70 flights per hour or within 24 hours (calculated from total Flight number of 1687 divided by 24 hours) was still below the airport standard of 72 flights per hour. However, when viewed closely with the actual flight schedule on the table, it was found that there were some constraints or problems in which during 24-hour flight time there were six hours or times which was considered as the critical category because it covered more than 100 flights per hour.

The analysis of the aircraft movement results per hour was according to the peak and low hour of on aircraft movement. On table one, it appeared that the peak hour of the aircraft movement was at 17.00-18.00 local time with the 
number of the departure as many as 51 flights and the number of arrival as many as 66 flights, totally both 117 flights. On the other hand, the low hour of flight movement was at 03.00-04.00 local time with only two flights. Then, based on the benchmarking from the other three airports in the world on table two, we can see Heathrow International Airports as the crowded airport with runway capacity of 89 flights per hour. Soekarno-Hatta International Airport, on the other hand, had the lowest number of aircraft movements with runway capacity of 72 flights per hour. In fact, both airports had similarity in which they had two runways. The difference of those two airports was on the cross taxiway. Heathrow International airport had seven cross taxiways while Soekarno-Hatta international airport only had one cross taxiway with two runways. This fact indicated that Heathrow was able to serve more flights or movements. In contrast, because of limited number of cross taxiway, flights at Soekarno-Hatta International Airport would need to queue before landing and taking-off.

From table two, the Heathrow International Airport with 474,463 aircraft movements had the largest number of aircraft movements compared with the other three countries above and the Heathrow International Airport could accommodate 89 flights per hour using the same multiple runways, While Kuala Lumpur International Airport was put on the last rank with 242,615 aircraft movements accumulation and it is runway could accommodate aircraft with total 78 flights per hour. And then, the interviews on November 7 and 8, 2017, revealed that runway occupancy time at Soekarno-Hatta International Airport was 72 flights per hour. Approximately for one hour in one runway it could accommodate 36 aircrafts or flights per hour. Runway at Soekarno-Hatta International Airport had already met the safety standards as shown from the number of flight using Soekarno-Hatta International Airport. The interview revealed that by using exit rapid taxiway and east cross taxiway it was expected to be able to increase the movement of aircraft and make the movement of the 
aircraft to be more dynamic. Though the construction of the third runway at the Soekarno-Hatta International Airport is no longer very important today, it is still in demand considering the trend of increasing number of flights every year at this airport.

Based on the results of flight schedule, benchmarking with other airports, and interviews, it can be concluded that with only two runways, SoekarnoHatta International Airport was incapable to handle air traffic flights properly since it was considered overcapacity to handle more than 72 aircraft movements in 15 different times.

Figure 1.

Map of Soekarno-Hatta International Airport and London Heathrow International Airport with Cross Taxiway

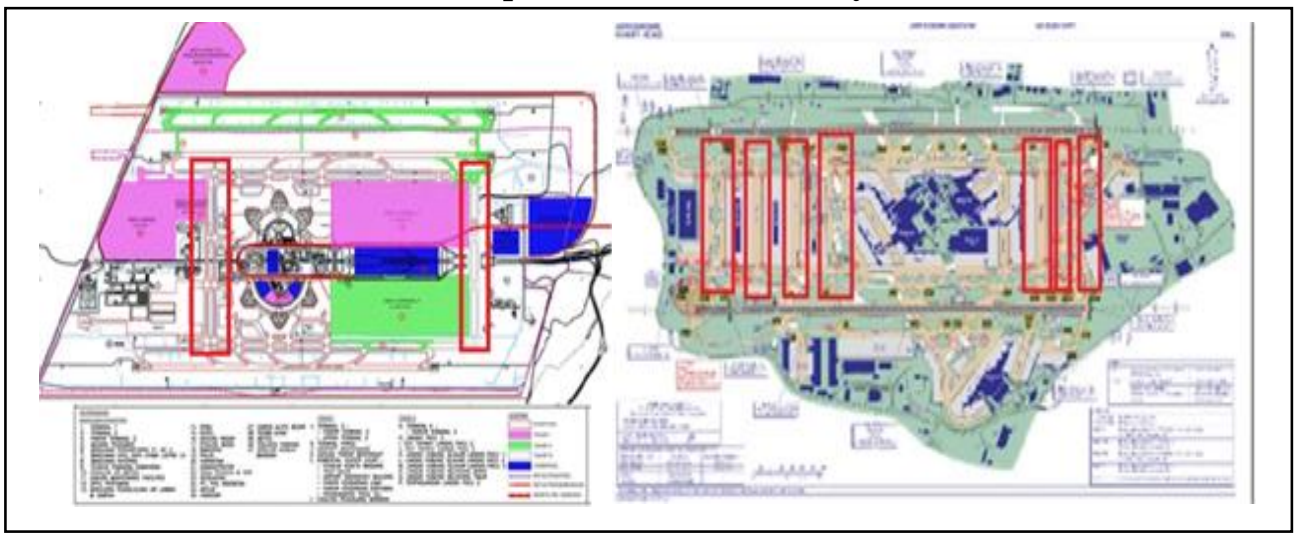

Hence, the construction of the third runway at Soekarno-Hatta International Airport could become a solution of the flight traffic and to ease the air traffic movement. This will increase the level of aircraft movement from 72 to 90 movements per hour, meaning that the third runway can facilitate 2736 aircraft movements per day facilitating more aircrafts to take-off and land and overcoming the overloaded movements on certain hour. Also, this could increase the country's foreign exchange that can optimize the growth of Indonesian economy and tourism because it accommodates more number of aircraft passengers which is predicted to reach around 100 million passengers in 2025. Therefore, accessibility is the main function behind the basics of tourism transport (I. P. Ricardianto, Djajaputra, \& Martono, 2017). To add, providing 
three runways will give an advantage when one of the runways is under maintenance because the maintenance or so will not disturb the aircraft movements and keep the runway activities in the standard of safety level.

Therefore, it can be concluded that two runways are not sufficient compared with the number of aircraft movements that is increasing each year (see on table one), especially when considering the peak hours of runway utilization at 17.00-18.00 local time with 117 fights from total departure and arrival movements. With a total of 1687 flights coming or departing per day at Soekarno-Hatta International Airport, it is suggested that PT Angkasa Pura II as a BUMN increase the runway capacity and modify the taxiway, apron, cross taxiway, and terminal in order to accommodate the high level of air traffic movement at the Soekarno-Hatta International Airport.

\section{References}

Farhadi, F., Ghoniem, A., \& Al-Salem, M. (2014). Runway capacity management - An empirical study with application to Doha International Airport. Transportation Research Part E: Logistics and Transportation Review, 68, 53-63. https://doi.org/10.1016/j.tre.2014.05.004

Janić, M. (2017). Analysing and modelling some effects of solutions for matching the airport runway system capacity to demand. Journal of Air Transport Management, 1-15. https://doi.org/10.1016/j.jairtraman.2017.06.007

Martono, K., \& Marina, S. (n.d.). Domestic Air Transport Regulations in Indonesia, 3(1), 1-19.

Marty, Y. (2016). Airline Customer Retention in Indonesia 2015. International Journal of Management Sciences and Business Research, 2015(2), 41-53.

Perdamaian, L. G., Budiarto, R., \& Ridwan, M. K. (2013). Scenarios to Reduce Electricity Consumption and CO2 Emission at Terminal 3 Soekarno-Hatta International Airport. Procedia Environmental Sciences, 17, 576-585. https://doi.org/10.1016/j.proenv.2013.02.073

Ricardianto, I. P., Djajaputra, D. G., \& Martono, P. D. (2017). Air Transport and Tourism in Indonesia. IOSR Journal of Applied Chemistry, 10(5), 0119. https://doi.org/10.9790/5736-1005010119

Ricardianto, P., \& Rifni, M. (n.d.). Aerodrome Safety for Manouvering Area in Soekarno-Hatta International Airport Cengkareng, 2(3).

Simarmata, J., \& Keke, Y. (2017). The Influence of Travel Agent, 
Infrastructure and Accommodation on Tourist Satisfaction, 28(Ictgtd 2016), 281-283.

Skorupski, J., \& Wierzbicki, H. (2017). Airport capacity increase via the use of braking profiles. Transportation Research Part C: Emerging Technologies, 80, 467-484. https://doi.org/10.1016/j.trc.2016.05.016

Takebayashi, M. (2011). The runway capacity constraint and airlines' behavior: Choice of aircraft size and network design. Transportation Research Part E: Logistics and Transportation Review, 47(3), 390-400. https://doi.org/10.1016/j.tre.2010.11.010

Wilke, S., Majumdar, A., \& Ochieng, W. Y. (2015). Modelling runway incursion severity. Accident Analysis and Prevention, 79, 88-99. https://doi.org/10.1016/j.aap.2015.03.016

Zografos, K. G., Stamatopoulos, M. A., \& Odoni, A. R. (1997). An Analytical Model for Runway System Capacity Analysis. IFAC Proceedings Volumes, 30(8), 29-34. https://doi.org/10.1016/S1474-6670(17)43796-7 